\title{
ПРОБЛЕМЫ ПРАВОВОГО СТАТУСА УЧАСТНИКОВ СТРОИТЕЛЬСТВА КАК ЛИЦ УЧАСТВУЮЩИХ В ДЕЛЕ О БАНКРОТСТВЕ ЗАСТРОЙЩИКА
}

\author{
Машин Александр Алексеевич \\ Аспирант, ФГБОУ ВО «Саратовская \\ государственная
}

PROBLEMS OF THE LEGAL STATUS OF CONSTRUCTION PARTICIPANTS AS PERSONS PARTICIPATING IN THE BANKRUPTCY CASE OF THE DEVELOPER

A. Mashin

Summary. This article provides the definition and characteristics of the legal status of a participant in construction in bankruptcy cases of a developer. The author examines the organizational and legal forms of construction subjects who are allowed to act as a developer, analyzes the actual and legal criteria for recognizing a person as a developer. To substantiate the problem of determining the legal status of a developer, the work provides the provisions of regulatory legal acts and judicial practice. As a result of the study, the author comes to the conclusion that when categorizing construction objects, it is necessary to proceed not only from the actual provisions of bankruptcy legislation, but also from other current legislation, the purpose of the relevant law is the need to protect construction participants as a non-professional group of investors. When determining a developer, it is necessary to proceed from an expanded interpretation of the norms of bankruptcy legislation.

Keywords: bankruptcy, insolvency, developer, construction participant, protection of rights.

B соответствии с п. 2 п. 1 ст. 201.1 Федерального закона от 26.10.2002 № 127-Ф3 «О несостоятельности (банкротстве)» (далее - Закон о банкротстве) участником строительства является физическое лицо, юридическое лицо, Российская Федерация, субъект Российской Федерации или муниципальное образование, имеющее обязательство по передаче жилья или имущественный иск к застройщику [3].

Как отмечается А.П. Кузнецовым: «В отличие от обычной процедуры банкротства, при банкротстве застройщика стороны имеют особое название: должник называется застройщиком, а кредиторы - участниками строительства. Однако здесь следует сде- лать одну оговорку. Не все кредиторы задействованы в строительстве, но все участники строительства являются кредиторами» [6].

Федеральный закон «О банкротстве» содержит как общие положения, которые должны применяться ко всем категориям дел о банкротстве, так и положения особого характера, установленные отдельными параграфами и главами. Эти специальные правила устанавливают перечень характеристик, которые должны применяться в отношении определенных категорий должников. В законе выделены отдельные категории дел о банкротстве финансовых и городских организаций, субъектов естественных монополий, застрой- 
щиков. Необходимость особого регулирования соответствующих категорий связана с особым правовым статусом и статусом лиц, участвующих в деле, возникновением особых требований к должнику, ролью государства и государственных институтов вместе с их механизмами в разрешении определенных споров.

Следует отметить, что статья 2 Федерального закона о банкротстве устанавливает сферу действия этого закона, и распространяется на юридических лиц, которые в соответствии с Гражданским кодексом Российской Федерации могут быть признаны неплатежеспособными. Таким образом, регулирование данного нормативного правового акта касается деятельности юридических лиц, пределов ограничений такой деятельности, критериев признания лица банкротом.

Под юридическим лицом ст. 48 Гражданский кодекс понимает организацию, которая имеет обособленное имущество и несет ответственность за такое имущество по своим обязательствам, а также которая имеет право от своего имени приобретать и осуществлять гражданские права, нести гражданские обязанности, быть истцом и ответчиком в суде [1].

Когда граждане, индивидуальные предприниматели или юридические лица принимают решение об объединении капитала таким образом, чтобы имущество этих субъектов гражданского оборота в случае неблагоприятных финансовых последствий для такой организации было наиболее защищено от невыполненных обязательств, то наилучшим решением будет объединение капитала в юридическую организационно-правовую форму общества с ограниченной ответственностью. В случае объединения капитала в такую организационно-правовую форму каждый из участников вносит в общий капитал организации определенную долю средств или других активов. Впоследствии, если возникнет ситуация, при которой необходимо будет выполнить обязательства организации, включая погашение долгов кредиторам, максимум, что могут потерять участники компании, - это имущество или средства, внесенные в уставный капитал общества с ограниченной ответственностью [7]. Однако законодатель не ограничил перечень организационно-правовых форм, которым разрешено выступать в качестве застройщика, что подразумевает право любого юридического лица привлекать средства участников строительства и строить дома.

В исключительных случаях в федеральном законе о банкротстве особое внимание уделяется жилищным и строительным кооперативам, которые в соответствии с жилищным кодексом признают добровольное объединение граждан, а в случаях юридических лиц, учрежденных жилищным кодексом и другими федеральными законами о членстве, - соответствовать требованиям потребности граждан в жилье, а также управление многоквартирным домом [5]. Таким образом, законом предусмотрено, что члены этих кооперативов за свой счет и имущества участвуют в строительстве или реконструкции многоквартирного дома [8].

Следует отметить, что в Федеральном законе «Об участии в долевом строительстве» к застройщику также относится некоммерческая организация, созданная в соответствии с Законом Российской Федерации от 15 апреля 1993 г. № 4802-1 «О статусе столицы Российской Федерации». Таким образом, Московский фонд реновации жилой застройки - это унитарная некоммерческая организация, созданная в организационно-правовой форме фонда [4]. Данная организация по своей правовой природе и способу регулирования является достаточно частной формой застройщика, поскольку законодательством предусмотрен ряд исключений из общих положений федерального закона и предусмотрены многие функции по регулированию деятельности этого фонда. Так, специальные нормы, предусмотренные Законом о статусе столицы Российской Федерации, а также нормативными правовыми актами города Москвы, указывают на особый статус этой некоммерческой организации. Указанные нормативные акты регулируют, что на Московский фонд реновации жилой застройки не распространяются общие нормы пунктов 3, 5, 7, 10 ст. 32; п. 1 ст. 7 Федерального закона от 12 января 1996 г. № 7-Ф3 «О некоммерческих организациях» (далее - Федеральный закон о некоммерческих организациях). Кроме того, законодательством города Москвы предусмотрены дополнительные гарантии права на жилище и имущество граждан и юридических лиц. Так, в соответствии с Законом города Москвы от 17 мая 2017 года № 14 «О дополнительных гарантиях жилищных и имущественных прав физических и юридических лиц при осуществлении реновации жилого фонда в городе Москве» для собственников жилых помещений, подлежащих ремонту, предоставляется эквивалентная жилая площадь (равной жилой площади, с таким же количеством комнат, в таком же районе Москвы)[5].

Кроме того, Федеральный закон о банкротстве регулирует отношения, связанные с несостоятельностью граждан и индивидуальных предпринимателей. Это не исключает признания банкротства индивидуального предпринимателя, выступающего застройщиком. Соответственно, отношения, регулируемые пунктом 7 Федерального закона о банкротстве, также являются предметом несостоятельности индивидуального предпринимателя, в отношении которого существуют 
юридические требования о передаче жилищных или денежных требований.

Итак, как уже установлено, Федеральный закон «О банкротстве» достаточно лоялен к списку лиц, которые могут выступать застройщиком, однако, несмотря на это, наличие государственной регистрации обязательно. В связи с тем, что по критерию организационно-правовой формы в законодательстве о банкротстве нет исключений, то первым признаком застройщика следует учитывать: привлечение денежных средств и имущества участников строительства. Эта особенность важна, потому что в случае неплатежеспособности застройщика участником может стать только лицо, получившее от граждан средства для финансирования строительства жилого дома или других объектов недвижимости.

Таким образом, о цели финансирования жилого дома или другого объекта недвижимости уже не раз говорилось. Тип строительного объекта имеет большое значение при определении застройщика, поскольку в разделе 7 Федерального закона о банкротстве говорится, что строительным объектом может считаться только жилой дом или многоквартирный дом, состоящий из трех или более блоков. В этом случае, если лицо привлекло средства на строительство гаражей или, например, учебного заведения, то положения Ф3 о банкротстве застройщика в данном случае не применяются, поскольку субъект не является застройщиком. Также стоит отметить, что такой объект строительства, как жилой дом блокированной застройки, имеет свои особенности, которые законодатель заложил в самом понятии данной категории.

Таким образом, дом блокированной застройки имеет характер жилого дома. Эта квалификационная особенность указана не случайно, поскольку многие гаражные кооперативы, которые по структуре схожи с блокированными зданиями, относятся к блокированной застройке. Несмотря на это сходство, они имеют несколько иное назначение и функциональность, что противоречит целям законодательства о банкротстве.

В закон также включен Фонд защиты прав граждан - участников совместного строительства в составе группы лиц, подпадающих под действие законодательства о банкротстве застройщика. Деятельность этого фонда регулируется Федеральным законом от 29 июля 2017 г. № 218-Ф3 «О публично-правовой компании по защите прав граждан - участников долевого строительства при несостоятельности (банкротстве) застройщиков и о внесении изменений в отдельные законодательные акты Российской Федерации», настоящим Федеральным законом также регулируется порядок создание такой организации определяет их правовой статус и цели, а также устанавливает полномочия такого фонда

Также довольно интересна практика Верховного Суда РФ, в которую входят такие категории людей, которые, по сути, не соответствуют установленным требованиям и критериям. Так, Верховный суд РФ отметил, что застройщиком может считаться не только лицо, с которым заключены договоры о совместном строительстве, но и люди, собирающие средства на строительство жилого дома. Этот прецедент был установлен определением № 304-ES16-4218.

Итак, суд первой инстанции установили, что аффилированная с застройщиком компания не может быть признана застройщиком, так как не имеет обязательств перед участниками строительства и не занимается привлечением денежных средств лично. Таким образом, суды первой инстанции исходили из фактического толкования правил Ф3 О банкротстве, но Верховный суд установил, что при категоризации объектов строительства необходимо исходить не только из фактических положений законодательства о банкротстве, но и из действующего законодательства, цели соответствующего закона - необходимость защиты участников строительства как непрофессиональной группы инвесторов.

В результате Судебная коллегия Верховного Суда РФ отменила акты нижестоящих судов и направила данный спор на новое рассмотрение, указав следующие мотивы этого решения. Закон о банкротстве не исключает возможности признания за организацией статуса застройщика, если это лицо владеет землей и объектом строительства и фактически привлекает средства для соответствующего строительства. Таким образом, Верховный Суд Российской Федерации признал договорные структуры между участниками строительства и кооперативом притворными, а аффилированное с кооперативом лицо фактическим застройщиком.

Поэтому Федеральный закон о банкротстве вполне соответствует концепции застройщика. Фактические критерии, установленные в соответствующем законе, не ограничиваются своей правовой природой. При определении застройщика необходимо исходить из расширенного толкования этих норм, а также из целей данного закона. Кроме того, несмотря на достаточно свободное толкование положений Федерального закона о банкротстве с точки зрения признания лица застройщиком, законом также устанавливаются конкретные юридические лица, которые, согласно закону, признаются участвующими в соответствующей категории дел о банкротстве. 


\section{ЛИТЕРАТУРА}

1. Гражданский кодекс РФ Ч. 1: федер. закон № 51-ФЗ от 30 ноября 1994 г. в ред. от 26.07.2017 № 199-ФЗ // Собрание Законодательства РФ. 1994 г. № 32. Ст. 3302.

2. Ж Жилищный кодекс РФ: федер. закон № 188-Ф3 от 29 декабря 2004 г. в ред. от 29.07.2020 № 258-Ф3 // Собрание законодательства РФ. 2005. № 1. Ст. 14.

3. Федеральный закон от 26.10.2002 № 127-Ф3 (ред. от 03.07.2016) «0 несостоятельности (банкротстве)» (с изм. и доп., вступ. в силу с 01.01.2017) // СПС «КонсультантПлюс». [Электронный ресурс]. Режим доступа: http://www.consultant.ru/ (дата обращения: 07.03.2021).

4. 0 статусе столицы Российской Федерации: закон РФ № 48021 от 15 апреля 1993 г. в ред. от 29.07.2017 218-Ф3 // Собрание законодательства РФ. 1993 г. № 19. Ст. 683.

5. 0 дополнительных гарантиях жилищных и имущественных прав физических и юридических лиц при осуществлении реновации жилищного фонда в городе Москве: закон г. Москвы № 14 от 17 мая 2017 г. [электронный ресурс] // СПС «Гарант».— Режим доступа: www.garant.ru (дата обращения 07.03.2021)

6. Кузнецов А.П. Банкротство застройщика: теория и практика защиты прав граждан -участников строительства. М.: Статут, 2015.96 с.

7. Гражданское право: Учебник: в 3т. Т. 1 / под ред. В.П. Мозолина — 2-е изд., перераб. и доп. — М.: Проспект, 2016. - 816 с.

8. Барабина, М.П. Проблемы незавершенного строительства в рамках дела о банкротстве застройщика — введение нового «Механизма» замены застройщика при банкротстве / Барабина М.П. // Право и экономика. — 2016. — № 7.—C. 23-26.

\footnotetext{
๑) Машин Александр Алексеевич ( mashin.a.a.64rus@gmail.com ).
}

Журнал «Современная наука: актуальные проблемы теории и практики»

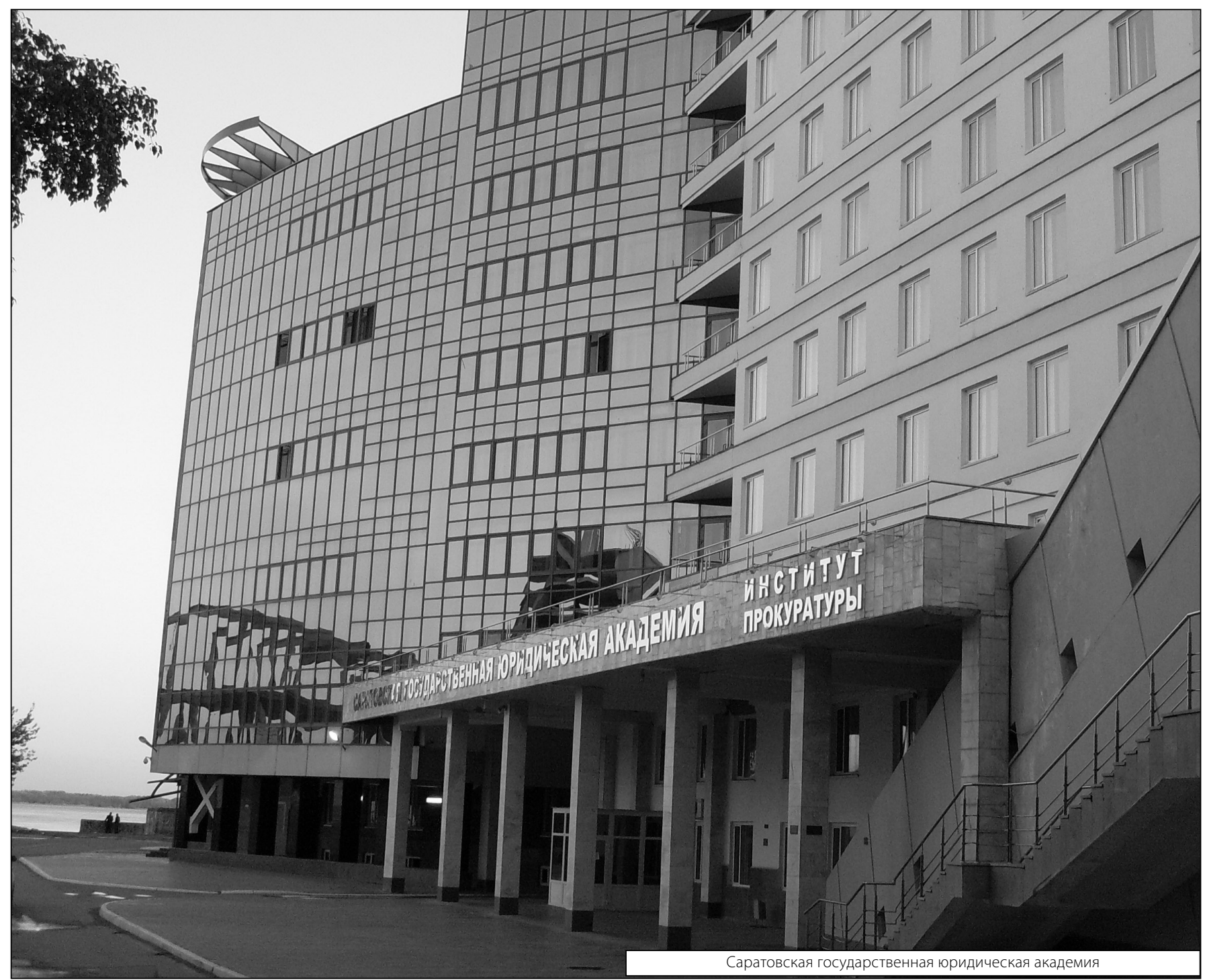

